University of Wollongong

Research Online

Faculty of Engineering and Information

Faculty of Engineering and Information

Sciences - Papers: Part A

Sciences

$1-1-2014$

In-situ neutron diffraction study of the simultaneous structural evolution of

a LiNiO.5Mn1.504 cathode and a Li4Ti5012 anode in a

LiNi0.5Mn1.504||Li4Ti5012 full cell

Wei Kong Pang

Tatung University, wkpang@uow.edu.au

Neeraj Sharma

ANSTO

Vanessa K. Peterson

ANSTO

Je-Jang Shiu

Tatung University Taipei

She-huang Wu

Tatung University Taipei

Follow this and additional works at: https://ro.uow.edu.au/eispapers

Part of the Engineering Commons, and the Science and Technology Studies Commons

Research Online is the open access institutional repository for the University of Wollongong. For further information contact the UOW Library: research-pubs@uow.edu.au 


\title{
In-situ neutron diffraction study of the simultaneous structural evolution of a LiNi0.5Mn1.504 cathode and a Li4Ti5012 anode in a LiNi0.5Mn1.504||Li4Ti5012 full cell
}

\begin{abstract}
In this study, the application of neutron powder diffraction on studying the time-resolved structural evolution of a cell comprised with LiNi $0.5 \mathrm{Mn} 1.504$ cathode and Li4Ti 5012 anode during chargedischarge cycling is demonstrated. As expected, the lattices of the LiNi0.5Mn 1.504 cathode and the Li4Ti50 12 anode in the cell are found to simultaneously contract during charging and expand during discharging. It is found that for the LiNi $0.5 \mathrm{Mn} 1.504$ cathode a solid-solution reaction is associated with the lattice change and the $\mathrm{Ni2}+/ \mathrm{Ni} 3+$ redox couple between 3.06 and 3.16 V (vs. Li4Ti50 12), and a twophase reaction between LixNi $0.5 \mathrm{Mn} 1.504$ and $\mathrm{Ni} 0.25 \mathrm{Mn} 0.7502$ is corresponding to the $\mathrm{Ni3}+\mathrm{Ni} 4+$ redox couple at voltage higher than $3.22 \mathrm{~V}$ (vs. Li 4Ti5012) without a corresponding change in lattice. The oxidation states of the metals in the electrodes are determined by tracking the associated change in the oxygen position. In addition, the Ti oxidation state is correlated to the intensity of the Li4Ti 5012222 reflection at the anode, and the determined oxidation state of the $\mathrm{Ni}$ is correlated to the lithium occupancy within the cathode. Furthermore, the small volume changes of the cathode and the anode upon cycling suggest that the cell chemistry is favorable for practical applications.
\end{abstract}

\section{Keywords}

lithium ion battery, in-situ neutron diffraction, lithium nickel manganese oxide, lithium titanium oxide, full cell, structural evolution

Disciplines

Engineering | Science and Technology Studies

\section{Publication Details}

Pang, W., Sharma, N., Peterson, V. K., Shiu, J. \& Wu, S. (2014). In-situ neutron diffraction study of the simultaneous structural evolution of a LiNi0.5Mn1.504 cathode and a Li4Ti5012 anode in a LiNi0.5Mn1.504||Li4Ti5012 full cell. Journal of Power Sources, 246 464-472. 
In-situ neutron diffraction study of the simultaneous structural evolution of a

$\mathrm{LiNi}_{0.5} \mathrm{Mn}_{1.5} \mathrm{O}_{4}$ cathode and $\mathrm{Li}_{4} \mathrm{Ti}_{5} \mathrm{O}_{12}$ anode in $\mathrm{LiNi} \mathrm{Li}_{0.5} \mathrm{Mn}_{1.5} \mathrm{O}_{4}|| \mathrm{Li}_{4} \mathrm{Ti}_{5} \mathrm{O}_{12}$ full

cell.

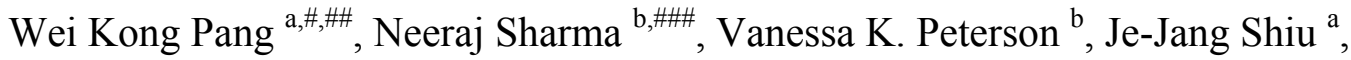
and She-huang $\mathrm{Wu}^{\mathrm{a}, *}$.

${ }^{a}$ Department of Materials Engineering, Tatung University, No.40, Sec. 3,

Zhongshan N. Rd., Taipei City 104, Taiwan (R.O.C).

${ }^{\mathrm{b}}$ Australian Nuclear Science and Technology Organisation, Locked Bag 2001,

Kirrawee DC, NSW 2232, Australia.

For: Journal of Power Sources

*Corresponding author. Tel.: +886-2-25922458; fax:+886-2-25936897, Email: shwu@ttu.edu.tw

\# Present address: Australian Nuclear Science and Technology Organisation, Locked Bag 2001, Kirrawee DC, NSW 2232, Australia.

\#\# Present address: School of Mechanical, Materials, and Mechatronic Engineering, Institute for Superconducting \& Electronic

Materials, Faculty of Engineering, University of Wollongong, NSW 2522, Australia.

\#\#\# Present address: School of Chemistry, University of New South Wales, Sydney NSW 2052, Australia. 
Abstract

In this study, the application of neutron powder diffraction on studying the time-resolved structural evolution of a cell comprised with $\mathrm{LiNi}_{0.5} \mathrm{Mn}_{1.5} \mathrm{O}_{4}$ cathode and $\mathrm{Li}_{4} \mathrm{Ti}_{5} \mathrm{O}_{12}$ anode during charge-discharge cycling is demonstrated. As expected, the lattices of the $\mathrm{LiNi}_{0.5} \mathrm{Mn}_{1.5} \mathrm{O}_{4}$ cathode and the $\mathrm{Li}_{4} \mathrm{Ti}_{5} \mathrm{O}_{12}$ anode in the cell are found to simultaneously contract during charging and expand during discharging. It is found that for the $\mathrm{LiNi}_{0.5} \mathrm{Mn}_{1.5} \mathrm{O}_{4}$ cathode a solid-solution reaction is associated with the lattice change and the $\mathrm{Ni}^{2+} / \mathrm{Ni}^{3+}$ redox couple between 3.06 and $3.16 \mathrm{~V}$ ( $\mathrm{vs}$. $\mathrm{Li}_{4} \mathrm{Ti}_{5} \mathrm{O}_{12}$ ), and a two-phase reaction between $\mathrm{Li}_{x} \mathrm{Ni}_{0.5} \mathrm{Mn}_{1.5} \mathrm{O}_{4}$ and $\mathrm{Ni}_{0.25} \mathrm{Mn}_{0.75} \mathrm{O}_{2}$ is corresponding to the $\mathrm{Ni}^{3+} / \mathrm{Ni}^{4+}$ redox couple at voltage higher than $3.22 \mathrm{~V}\left(\mathrm{vs} . \mathrm{Li}_{4} \mathrm{Ti}_{5} \mathrm{O}_{12}\right.$ ) without a corresponding change in lattice. These results show that the $\mathrm{LiNi}_{0.5} \mathrm{Mn}_{1.5} \mathrm{O}_{4} \| \mathrm{Li}_{4} \mathrm{Ti}_{5} \mathrm{O}_{12}$ cell is a promising battery system with a high columbic and energy efficiency. The oxidation states of the metals in the electrodes are determined by tracking the associated change in the oxygen position. In addition, the $\mathrm{Ti}$ oxidation state is correlated to the intensity of the $\mathrm{Li}_{4} \mathrm{Ti}_{5} \mathrm{O}_{12} 222$ reflection at the anode, and the determined oxidation state of the $\mathrm{Ni}$ is correlated to the lithium occupancy within the cathode. Furthermore, the small volume changes of the cathode and the anode upon cycling suggest that the cell chemistry is favorable for practical applications. 
Keywords: lithium ion battery; in-situ neutron diffraction; lithium nickel manganese oxide; lithium titanium oxide; full cell; structural evolution. 


\section{Introduction}

Lithium-ion batteries have not only become the major power sources for portable electronic devices, such as mobile phones, notebooks, and digital cameras, but are also considered elemental components of energy-storage devices for electrical vehicles and electrical energy storage systems. Safety is a key issue for these applications, with issues arising from the relatively small difference between the lithium intercalation potential of graphite and the $\mathrm{Li}^{+} / \mathrm{Li}$ reduction potential, leading to the growth of dendritic lithium on the surface of the anode that may induce short circuits and even battery rupture at overcharging or high rate charging conditions [1]. Spinel $\mathrm{Li}_{4} \mathrm{Ti}_{5} \mathrm{O}_{12}$, a zero-strain lithium insertion material [2], exhibits good reversibility at the $\mathrm{Ti}^{4+} / \mathrm{Ti}^{3+}$ redox reaction and a flat redox plateau at approximately $1.55 \mathrm{~V}$ vs. Li. Moreover, the formation of a solid electrolyte interface and Li metal electroplating on the surface of the anode can be prevented, likely as a result of the higher redox potential of $\mathrm{Li}_{4} \mathrm{Ti}_{5} \mathrm{O}_{12}$ compared to that of the undesirable electrolyte decomposition [3-6] and lithium metal deposition [7]. Consequently, $\mathrm{Li}_{4} \mathrm{Ti}_{5} \mathrm{O}_{12}$ is expected to be used as alternative anode to carbonaceous materials. Belharouak et al. reported that the $\mathrm{LiMn}_{2} \mathrm{O}_{4} \| \mathrm{Li}_{4} \mathrm{Ti}_{5} \mathrm{O}_{12}$ battery could be one of the safest Li-ion battery systems, based on factors such as good thermal stability, limited reactivity between the cell components and electrolyte, good 
structural stability, as well as the impossibility of thermal runaway, explosion or fire [8]. A $\mathrm{LiMn}_{2} \mathrm{O}_{4} \| \mathrm{Li}_{4} \mathrm{Ti}_{5} \mathrm{O}_{12}$ battery is also expected to have good electrochemical performance based on the intrinsic electrochemical properties of $\mathrm{Li}_{4} \mathrm{Ti}_{5} \mathrm{O}_{12}$ and $\mathrm{LiMn}_{2} \mathrm{O}_{4}$ [8], although its measured average working voltage of $2.5 \mathrm{~V}$ is lower than for other batteries [9-12]. In order to increase the working voltage and energy density without changing the desired characteristics of this kind of battery, $\mathrm{LiNi}_{0.5} \mathrm{Mn}_{1.5} \mathrm{O}_{4}$ may be used to replace $\mathrm{LiMn}_{2} \mathrm{O}_{4}$ as a cathode in the $\mathrm{LiMn}_{2} \mathrm{O}_{4} \| \mathrm{Li}_{4} \mathrm{Ti}_{5} \mathrm{O}_{12}$ cell to form a $\mathrm{LiNi}_{0.5} \mathrm{Mn}_{1.5} \mathrm{O}_{4} \| \mathrm{Li}_{4} \mathrm{Ti}_{5} \mathrm{O}_{12}$ cell with a higher working voltage and better cycling performance [13-16].

$\mathrm{LiNi}_{0.5} \mathrm{Mn}_{1.5} \mathrm{O}_{4}$ crystallizes into the ordered primitive $P 4_{3} 32$ symmetry phase with distinct cationic arrangements of $\mathrm{Li}^{+}(8 c), \mathrm{Ni}^{2+}(12 d)$, and $\mathrm{Mn}^{4+}(4 b)$, or the disordered face-centered $F d \overline{3} m$ symmetry phase with $16 d$ sites shared by $\mathrm{Ni}^{2+}$ and $\mathrm{Mn}^{4+}$ and $8 a$ sites occupied by $\mathrm{Li}^{+}[17,18]$. Although both variants are of the spinel family, the $F d \overline{3} m$ material exhibits superior charge-discharge rate capability compared to the $P 4_{3} 32$ material, with the $\mathrm{P}_{3} 32$ spinel thought to be responsible for performance decay upon cell cycling due to its higher impedance compared to the $F d \overline{3} m$ structure [19]. It was also reported that the $P 4_{3} 32$ spinel undergoes transformation to an intermediate phase exhibiting $F d \overline{3} m$ symmetry during delithiation, may suggesting a lower structural 
reversibility of the $\mathrm{P}_{3} 32$ form than that of the $F d \overline{3} m$ form, especially at high rates [20, 21]. Ariyoshi et al. studied the phase transition of the ordered $\mathrm{LiNi}_{0.5} \mathrm{Mn}_{1.5} \mathrm{O}_{4}$ phase during charging and reported that the $P_{3} 32$ form undergoes two cubic-cubic two-phase reactions $\left(\mathrm{LiNi}_{0.5} \mathrm{Mn}_{1.5} \mathrm{O}_{4}, a=8.17 \AA / \mathrm{Li}_{0.5} \mathrm{Ni}_{0.5} \mathrm{Mn}_{1.5} \mathrm{O}_{4}, a=8.09 \AA\right.$ at the $\mathrm{Ni}^{2+/ 3+}$ transition and $\mathrm{Li}_{0.5} \mathrm{Ni}_{0.5} \mathrm{Mn}_{1.5} \mathrm{O}_{4}, a=8.09 \AA \mathrm{Ni}_{0.5} \mathrm{Mn}_{1.5} \mathrm{O}_{4}, a=8.00 \AA$ at the $\mathrm{Ni}^{3+/ 4+}$ transition) upon charging, accompanied by a $6 \%$ change in lattice volume [22]. They also report that $F d \overline{3} m \mathrm{LiMn}_{2} \mathrm{O}_{4}$ undergoes a solid-solution and a two-phase reaction during delithiation [22]. Following from this, $\mathrm{LiNi}_{0.5} \mathrm{Mn}_{1.5} \mathrm{O}_{4}$ with $F d \overline{3} m$ symmetry is expected to show a similar delithiation mechanism as the $F d \overline{3} m \quad \mathrm{LiMn}_{2} \mathrm{O}_{4}$ phase, with lattice parameters of the intermediate phase(s) expected to be close to those of the $\mathrm{LiNi}_{0.5} \mathrm{Mn}_{1.5} \mathrm{O}_{4}$ phase with $P 4_{3} 32$ symmetry, as a result of the influence of the ionic radii of $\mathrm{Ni}$ ions. Spinel $\mathrm{Li}_{4} \mathrm{Ti}_{5} \mathrm{O}_{12}$-based materials, referred to as a zero-strain lithium insertion materials [2, 23-25], exhibit excellent stability during charge-discharge cycling as a result of their relatively small volume change $(<1 \%)$ upon lithiation/delithiation. However, the relatively small variation in the $\mathrm{Li}_{4} \mathrm{Ti}_{5} \mathrm{O}_{12}$ lattice on lithiation/delithiation makes its electrochemical-structural relation difficult to study. For example, the exact mechanism of the transformation of $\mathrm{Li}_{4} \mathrm{Ti}_{5} \mathrm{O}_{12}$ to the lithiated $\mathrm{Li}_{4} \mathrm{Ti}_{5} \mathrm{O}_{12}$ and to the 
excess-lithiated $\mathrm{Li}_{7+z} \mathrm{Ti}_{5} \mathrm{O}_{12}$ (where $0 \leq z \leq 2$ ) material under typical charge-discharge conditions remains controversial.

In this study, $\mathrm{LiNi}_{0.5} \mathrm{Mn}_{1.5} \mathrm{O}_{4}$ and $\mathrm{Li}_{4} \mathrm{Ti}_{5} \mathrm{O}_{12}$ powders are synthesized, structurally characterized using X-ray powder diffraction (XRPD) and high-resolution neutron powder diffraction (NPD), and used as active materials in a $\mathrm{LiNi}_{0.5} \mathrm{Mn}_{1.5} \mathrm{O}_{4}|| \mathrm{Li}_{4} \mathrm{Ti}_{5} \mathrm{O}_{12}$ cell. As XRPD has limited sensitivity to lighter elements, such as lithium, and limited scattering-factor contrast between near-neighbor elements on the periodic table such as Mn and Ni, further crystallographic studies were undertaken using high-resolution NPD. In the case of $\mathrm{LiNi}_{0.5} \mathrm{Mn}_{1.5} \mathrm{O}_{4}$, distinguishing between the two possible $F d \overline{3} m$ and $P_{3} 32$ symmetries is difficult considering their similar lattice parameters, with their major difference being the arrangement of the $\mathrm{Ni}$ and $\mathrm{Mn}$ atoms. Ni and $\mathrm{Mn}$ randomly occupy the $16 d$ site of the $F d \overline{3} m$ material, whereas the $\mathrm{Ni}$ and $\mathrm{Mn}$ reside at separate $4 b$ and $12 d$ sites, respectively, in the $P_{3} 32$ structure. Moreover, $\mathrm{Li}^{+}$ions occupy $8 a$ and $8 c$ sites, respectively, in the $F d \overline{3} m$ and $P 4_{3} 32$ materials. These structural differences between the two symmetries make NPD ideal for distinguishing them based on the elemental contrast offered by neutrons. High-resolution neutron diffraction has previously been used to distinguish the disordered $F d \overline{3} m$ and ordered $P 4_{3} 32$ phases of $\mathrm{LiNi}_{0.5} \mathrm{Mn}_{1.5} \mathrm{O}_{4}$ materials $[26,27]$. Bhaskar et al. studied the crystalline structure of 
$\mathrm{LiM}_{0.5} \mathrm{Mn}_{1.5} \mathrm{O}_{4}(\mathrm{M}=\mathrm{Fe}, \mathrm{Co}$, or $\mathrm{Ni})$ and found that the $600{ }^{\circ} \mathrm{C}$ annealed $\mathrm{LiM}_{0.5} \mathrm{Mn}_{1.5} \mathrm{O}_{4}$ with $\mathrm{M}=\mathrm{Fe}$ or Co crystalline forms the disordered $F d \overline{3} m$ form and that the material containing Ni formed the $\mathrm{P}_{3} 32$ structure with a high degree of $3 d$ cation disorder [26]. Moreover, while studying in-situ the phase evolution of $\mathrm{LiNi}_{0.5} \mathrm{Mn}_{1.5} \mathrm{O}_{4}$ at elevated temperatures, Cai et al. revealed that the $\mathrm{Ni} / \mathrm{Mn}$ ordering occurs slowly at $700{ }^{\circ} \mathrm{C}$ and the degree of ordering can be controlled by the annealing time [27]. Arguably, in-situ structural studies provide unparalleled insight into electrode functionality. In the case of neutron diffraction studies of lithium-ion batteries, sensitivity to lighter elements such as lithium can provide a direct measurement of lithium content and therefore battery capacity, and the sensitivity to oxygen, particularly in the presence of heavier elements, allows redox active couples to be probed through an examination of the transition metal valence by studying the oxygen to cation distance. Berg et al. studied the electrochemically induced $\mathrm{LiMn}_{2} \mathrm{O}_{4} / \lambda-\mathrm{MnO}_{2}$ phase transition using in-situ neutron diffraction [28]. More recently Cai et al. applied neutron diffraction to observe in situ the inhomogeneous degradation of large format Li-ion cells [29], and Sharma et al. have used in-situ ND extensively to study Li-ion batteries [30-37]. Importantly, neutrons provide bulk information as a result of their higher sample penetration compared to X-rays. 
In this work, the electrochemical functionality of the $\mathrm{LiNi}_{0.5} \mathrm{Mn}_{1.5} \mathrm{O}_{4} \| \mathrm{Li}_{4} \mathrm{Ti}_{5} \mathrm{O}_{12}$ cell is characterized and the simultaneous structural phase evolution of both the $\mathrm{LiNi}_{0.5} \mathrm{Mn}_{1.5} \mathrm{O}_{4}$ cathode and the $\mathrm{Li}_{4} \mathrm{Ti}_{5} \mathrm{O}_{12}$ anode upon electrochemical cycling are elucidated with the use of time-resolved in-situ NPD. The correlation between the electrochemical response of the cell and the structural evolution of the electrodes within is established and used to explain the working principle of the $\mathrm{LiNi}_{0.5} \mathrm{Mn}_{1.5} \mathrm{O}_{4}|| \mathrm{Li}_{4} \mathrm{Ti}_{5} \mathrm{O}_{12}$ cell.

\section{Experimental}

$\mathrm{LiNi}_{0.5} \mathrm{Mn}_{1.5} \mathrm{O}_{4}$ powders were prepared via spray pyrolysis. Citric acid (99.5\%), $\mathrm{LiNO}_{3}(100 \%), \mathrm{Mn}\left(\mathrm{NO}_{3}\right)_{2} \cdot 6 \mathrm{H}_{2} \mathrm{O}(98.0 \%)$, and $\mathrm{Ni}\left(\mathrm{NO}_{3}\right)_{2} \cdot 6 \mathrm{H}_{2} \mathrm{O}(98.0 \%)$, all from Wako Pure Chem. Ind. Ltd., Japan, were mixed stoichiometrically and stirred vigorously in an adequate amount of de-ionized water to form a solution at room temperature for 2 hours. The stoichiometric solution was spray-dried at $185^{\circ} \mathrm{C}$, and the remainder calcined at $300{ }^{\circ} \mathrm{C}$ in air for 2 hours. Finally, these powders were heated in air at a rate of $5{ }^{\circ} \mathrm{C} \min ^{-1}$ to $600{ }^{\circ} \mathrm{C}$ and kept at $600{ }^{\circ} \mathrm{C}$ for 6 hours followed by an isothermal hold at $800{ }^{\circ} \mathrm{C}$ for 8 hours before cooling. $\mathrm{Li}_{4} \mathrm{Ti}_{5} \mathrm{O}_{12}$ was prepared via a sol-gel method. Lithium acetate (98\%, Acros), tetrabutyltitanate (98\%, Acros), and citric acid (99.5\%, Acros) powders 
(in the ratio 4.2:5:1.25, respectively) were dissolved in an ethanol solution $(99.5 \%$, Shimakyu) and used as starting materials. The solution was prepared and aged for 3 hours to form a white-colored gel. The resulting gel was heated at $80{ }^{\circ} \mathrm{C}$ to yield an organic precursor, with a fine white powder obtained by heat-treating the precursor in air at $800{ }^{\circ} \mathrm{C}$ for 4 hours.

Diffraction data for the as-prepared individual electrode materials were collected on a Shimadzu Corporation $6000 \mathrm{X}$-ray powder diffractometer using $\mathrm{Cu}-\mathrm{K} \alpha$ radiation. In addition, high-resolution NPD data were also collected using ECHIDNA, the high-resolution neutron powder diffractometer at the Open Pool Australian Lightwater (OPAL) research reactor at the Australian Nuclear Science and Technology Organisation (ANSTO) [38]. A neutron beam with a wavelength of 1.6214(4) A, which was determined by using the $\mathrm{La}^{11} \mathrm{~B}_{6}$ NIST Standard Reference Material $660 \mathrm{~b}$, was used. The NPD data were obtained in the $2 \theta$ angular region 4 to $164^{\circ}$ with a step size of $0.125^{\circ}$. Rietica ver. 1.77 [39] was employed to perform Rietveld analysis of the high-resolution NPD data. The refineable parameters included the background coefficients, zero-shift, peak shape parameters, phase lattice, oxygen positional parameters, and isotropic atomic displacement parameters. The figures of merit for the refinement include the Bragg statistical reliability factor $\left(R_{B}\right)$, the weighted profile factor $\left(R_{w p}\right)$, the expected $R$ 
parameter $\left(\mathrm{R}_{\mathrm{exp}}\right)$, and the goodness-of-fit $\left(\chi^{2}\right.$, defined as the square of the ratio of $\left.\mathrm{R}_{\mathrm{wp}} / \mathrm{R}_{\mathrm{exp}}\right)$, and are presented in Figure 1 .

A specially designed cell was used for the collection of in-situ NPD data. For the cathode, as-prepared $\mathrm{LiNi}_{0.5} \mathrm{Mn}_{1.5} \mathrm{O}_{4}$ was mixed with polyvinylidene difluoride (PVDF) binder and acetylene black in the weight ratio of 83:7:10, respectively, in an adequate amount of N-methyl-2-pyrrolidinone to form a slurry. The slurry was tape-cast onto an aluminum foil and dried at $120^{\circ} \mathrm{C}$ for 24 hours. Negative electrodes were prepared using the same procedure, but with $\mathrm{Li}_{4} \mathrm{Ti}_{5} \mathrm{O}_{12}$ powder as active material and copper foil as the current collector. The loading ratio between the anode and cathode was designed to be 1.1 to 1 in capacity $(\mathrm{mA} \mathrm{h})$. The electrodes were cut into $1 \mathrm{~cm} \times 4 \mathrm{~cm}$ strips. Immobilon-P PVDF membrane (Millipore) was used as a separator due to its lower hydrogen content relative to the conventionally-used Celgard membrane. The $\mathrm{LiNi}_{0.5} \mathrm{Mn}_{1.5} \mathrm{O}_{4} \| \mathrm{Li}_{4} \mathrm{Ti}_{5} \mathrm{O}_{12}$ cell was prepared by stacking 30 anode/separator/cathode assemblies with a parallel connection. The stack was placed in an Ar-filled glove box for 24 hours and then wrapped in a polypropylene-coated aluminum bag. The dimension of the prepared cell was $1.5 \mathrm{~cm}$ wide (including sealed part of aluminum bag), $10 \mathrm{~cm}$ long ( including electrode handles), and $1 \mathrm{~cm}$ thick. Prior to the in-situ neutron experiment, deuterated electrolyte solution $\left(1 \mathrm{M} \mathrm{LiPF}_{6}\right.$ in a 1:1 volume ratio of deuterated dimethyl 
carbonate to deuterated ethylene carbonate) was injected into the bag and the bag heat-sealed under Ar. After 1-day of wetting, the cell underwent an electrochemical charge-discharge process at $9 \mathrm{~mA}$ to confirm the workability of the cell. During the in-situ neutron experiment the cell was cycled galvanostatically using a potentiostat/galvanostat (Autolab PG302N) at currents of 5, 9, and $18 \mathrm{~mA}$ (theoretically equivalent to $0.055,0.1$, and $0.2 \mathrm{C}$, respectively) for 3 cycles between 2.0 and $3.6 \mathrm{~V}$ (vs. $\mathrm{Li}_{4} \mathrm{Ti}_{5} \mathrm{O}_{12}$ ). This was followed by a rapid charging and discharging step (at $90 \mathrm{~mA}$ ) with constant voltage steps at 3.6 and $2.0 \mathrm{~V}$ for 5 hours.

In-situ NPD data of the $\mathrm{LiNi}_{0.5} \mathrm{Mn}_{1.5} \mathrm{O}_{4} \| \mathrm{Li}_{4} \mathrm{Ti}_{5} \mathrm{O}_{12}$ cell were collected using WOMBAT [40], the high-intensity neutron powder diffractometer at the OPAL research reactor at ANSTO. WOMBAT features an area detector that continuously covers $120^{\circ}$ in $2 \theta$ and a relatively intense neutron beam allowing that rapid collection of data. A neutron beam with a wavelength of 2.9591(5) $\AA$ was used, determined using the $\mathrm{Al}_{2} \mathrm{O}_{3}$ standard NIST Standard Reference Material 676. This instrument has been previously successfully used for in-situ NPD experiments on battery materials [30-32, 34-36]. The diffractograms were continuously obtained with an exposure time of 5 minutes per pattern in the angular range between 26.5 and $146.5^{\circ}$ in $2 \theta$. Sequential Rietveld refinements were carried out using Fullprof with visualization undertaken in WinplotR 
$[41,42]$. The refinements were performed using data in the range between 60 and $140^{\circ}$ in $2 \theta$. The figures of merit for the refinement include $\mathrm{R}_{\mathrm{B}}, \mathrm{R}_{\mathrm{wp}}, \mathrm{R}_{\mathrm{exp}}$, and $\chi^{2}$ are presented in Table $\mathrm{S} 1$ and $\mathrm{S} 2$ (Supporting Information). Single-peak fitting of the $\mathrm{Li}_{4} \mathrm{Ti}_{5} \mathrm{O}_{12} 222$, $\mathrm{LiNi}_{0.5} \mathrm{Mn}_{1.5} \mathrm{O}_{4} 222$ and 004, and $\mathrm{Cu} 222$ reflections were performed using the Large Array Manipulation Program (LAMP) [43].

\section{Results and Discussion}

XRPD data (Figure S1 in the Supporting Information) are used to determine the phase purity of the as-synthesized samples. $F d \overline{3} m \quad \mathrm{LiNi}_{0.5} \mathrm{Mn}_{1.5} \mathrm{O}_{4}$ with a minor amount of $\mathrm{NiO}$ is detected in the as-synthesized $\mathrm{LiNi}_{0.5} \mathrm{Mn}_{1.5} \mathrm{O}_{4}$ sample, whereas $F d \overline{3} m$ $\mathrm{Li}_{4} \mathrm{Ti}_{5} \mathrm{O}_{12}$ is phase pure. To reveal more information about the as-synthesized samples, high-resolution NPD data were collected and shown in Figure 1. Figure 1(a) shows the high-resolution NPD pattern of $\mathrm{LiNi}_{0.5} \mathrm{Mn}_{1.5} \mathrm{O}_{4}$ and the calculated pattern using the refined structural models of $F d \overline{3} m$ [17] and $P 4_{3} 32$ [18] $\mathrm{LiNi}_{0.5} \mathrm{Mn}_{1.5} \mathrm{O}_{4}$. The NPD data for the $\mathrm{LiNi}_{0.5} \mathrm{Mn}_{1.5} \mathrm{O}_{4}$ sample reveals both $F d \overline{3} m\left(77 \pm 2\right.$ wt.\%) and $P 4_{3} 32(22 \pm 1$ wt.\%) phases in an approximately 3:1 ratio. Only the major $F d \overline{3} m$ phase is considered in the following discussion of the $\mathrm{LiNi}_{0.5} \mathrm{Mn}_{1.5} \mathrm{O}_{4}$ lithiation-delithiation mechanism. The NPD data also reveal a small quantity of $\mathrm{NiO}[44](1.1 \pm 0.2 \mathrm{wt} . \%)$ in the as-synthesized 
$\mathrm{LiNi}_{0.5} \mathrm{Mn}_{1.5} \mathrm{O}_{4}$ sample. The effect of the $\mathrm{NiO}$ phase on overall $\mathrm{Li}$ conduction in the battery is unknown, but it is expected to lower the specific capacity of the $\mathrm{LiNi}_{0.5} \mathrm{Mn}_{1.5} \mathrm{O}_{4}[45,46]$, although the relatively minor amount of $\mathrm{NiO}$ present means that this effect is also small. We note that additional plateaus are not observed in the charge-discharge curve for the composite electrode, meaning that the effect of the $\mathrm{NiO}$ phase on the electrochemical behavior is small and not able to be measured. Therefore, we do not consider the $\mathrm{NiO}$ in the remainder of the work, despite our confirmation of the cathode as a composite electrode. Figure 1(b) shows the refinement plot using the high-resolution NPD data of the $\mathrm{Li}_{4} \mathrm{Ti}_{5} \mathrm{O}_{12}$ sample, starting from a previously-published structural model [47]. A small amount of $\mathrm{Li}_{2} \mathrm{TiO}_{3}(C 2 / m)[48](2.5 \pm 0.3$ wt.\%) was also found in the $\mathrm{Li}_{4} \mathrm{Ti}_{5} \mathrm{O}_{12}$ sample using NPD. The lattice and atomic parameters determined for the as-synthesized $\mathrm{LiNi}_{0.5} \mathrm{Mn}_{1.5} \mathrm{O}_{4}$ and $\mathrm{Li}_{4} \mathrm{Ti}_{5} \mathrm{O}_{12}$ are summarized in Table 1 .

Typical refinements using the in-situ high-intensity NPD dataset of the assembled $\mathrm{LiMn}_{1.5} \mathrm{Ni}_{0.5} \mathrm{O}_{4} \| \mathrm{Li}_{4} \mathrm{Ti}_{5} \mathrm{O}_{12}$ cell during charge-discharge cycling, shown for the charged and discharges state, are given in Figure $2 \mathrm{a}$ and $\mathrm{b}$, respectively. In the in-situ neutron diffraction data the ordered $\mathrm{LiNi}_{0.5} \mathrm{Mn}_{1.5} \mathrm{O}_{4}$ phase is unobservable as a result of the significant background contribution from hydrogen-containing battery components. As the ordered $\mathrm{LiNi}_{0.5} \mathrm{Mn}_{1.5} \mathrm{O}_{4}$ phase is only $22 \mathrm{wt} . \%$ of the active electrode (as determined 
in the high-resolution NPD study), it is not surprising that we cannot observe this phase in the in-situ experiment that involves diffraction from the entire battery, rather than the single component as was the case for the high-resolution study. It is known that the ordered phase behaves nearly identically in terms of electrochemical performance during short cycling at a low rate, similar to that used in this study [21]. Therefore, we describe only the delithiation/lithiation mechanism of the disordered phase in the following discussion.

Figure 3(a) shows the time-evolution of a selected $Q$ value region of the in-situ NPD patterns of the $\mathrm{LiMn}_{1.5} \mathrm{Ni}_{0.5} \mathrm{O}_{4}|| \mathrm{Li}_{4} \mathrm{Ti}_{5} \mathrm{O}_{12}$ cell collected during the entire experiment and Figure 3(b) is a subset of Figure 3(a), showing NPD patterns collected in the $2^{\text {nd }}$ cycle performed at a current of $5 \mathrm{~mA}$. The shifts in the $\mathrm{Q}$ value and intensity variation for the active materials' reflections arise as a result of lithiation/delithiation.

Multi-phase Rietveld refinement was performed sequentially using the entire in-situ NPD dataset and selected Rietveld-refined fits are shown in Figure 2(a) and 2(b) with the figure-of-merits summarized in the Supporting Information (Tables S1 and S2). In the Rietveld refinements using the entire in-situ NPD dataset, the $\mathrm{Ni}_{0.25} \mathrm{Mn}_{0.75} \mathrm{O}_{2}$ phase is modeled as being iso-structural to the disordered rocksalt-type $\mathrm{MnO}_{2}$, following previous work investigating delithiated $\mathrm{Li}_{x} \mathrm{MnO}_{2}$ [49]. Rietveld refinement results 
reveal that $\mathrm{Ni}_{0.25} \mathrm{Mn}_{0.75} \mathrm{O}_{2}$ features the slightly smaller lattice parameter of 4.000(7) $\AA$ than that of $\mathrm{MnO}_{2}$ due to the smaller ionic radius of $\mathrm{Ni}^{4+}$ relative to $\mathrm{Mn}^{4+}$. The $\mathrm{Ni}_{0.25} \mathrm{Mn}_{0.75} \mathrm{O}_{2}$ phase differs from that of $\mathrm{Ni}_{0.5} \mathrm{Mn}_{1.5} \mathrm{O}_{4}$ (retaining $F d \overline{3} m$ symmetry as $\mathrm{LiNi}_{0.5} \mathrm{Mn}_{1.5} \mathrm{O}_{4}$ with $\left.a=8.00 \AA\right)$ [22], whereas in $\mathrm{Ni}_{0.25} \mathrm{Mn}_{0.75} \mathrm{O}_{2}(F m \overline{3} m)$ the $4 a$ site is occupied by both $\mathrm{Ni}^{4+}$ and $\mathrm{Mn}^{4+}$ ions in the ratio $1: 3$.

On charging, the absence of peak splitting and new peak emergence suggest that $\mathrm{LiNi}_{0.5} \mathrm{Mn}_{1.5} \mathrm{O}_{4}$ initially undergoes a solid-solution transition (gradual delithiation, see Figure 3(b)) during the $\mathrm{Ni}^{2+} / \mathrm{Ni}^{3+}$ voltage plateau to form a composition close to $\mathrm{Li}_{0.5} \mathrm{Ni}_{0.5} \mathrm{Mn}_{1.5} \mathrm{O}_{4}$ (see eq. 1a, showing the initial delithiation of $\mathrm{LiNi}_{0.5} \mathrm{Mn}_{1.5} \mathrm{O}_{4}$ on charging). The value of $x$ ' is estimated to be approximately 0.5 .

$$
\begin{aligned}
& \mathrm{Li}^{8 a}\left(\mathrm{Ni}_{1 / 2} \mathrm{Mn}_{3 / 2}\right)^{16 d} \mathrm{O}_{4}^{32 e} \stackrel{\sim 3.15 \mathrm{~V} \text { vs.LTO }}{\longleftrightarrow} \\
& \mathrm{Li}_{x^{\prime}}{ }^{8 a}\left(\mathrm{Ni}_{1 / 2} \mathrm{Mn}_{3 / 2}\right)^{16 d} \mathrm{O}_{4}{ }^{32 e}+\left(1-x^{\prime}\right) e^{-}+\left(1-x^{\prime}\right) \mathrm{Li}^{+}
\end{aligned}
$$

(1a)

Figures $3 b$ and $3 c$ reveal a two-phase reaction region for the $\mathrm{LiNi}_{0.5} \mathrm{Mn}_{1.5} \mathrm{O}_{4}$ cathode, demonstrated by the emergence and disappearance of a new Bragg reflection at $2.71 \AA^{-1}$ in $\mathrm{Q}$ value and the concerted disappearance and emergence of the $\mathrm{LiNi}_{0.5} \mathrm{Mn}_{1.5} \mathrm{O}_{4} 222$ reflection. At the beginning of the $\mathrm{Ni}^{3+} / \mathrm{Ni}^{4+}$ voltage plateau, the 
initiation of a two-phase transition is observed as evidenced by decreasing $\mathrm{Li}_{0.5} \mathrm{Ni}_{0.5} \mathrm{Mn}_{1.5} \mathrm{O}_{4} 222$ reflection intensity and the increasing intensity of a new reflection (Figures $3 b$ and $3 c$ ). The new reflection is consistent with the appearance of the fully delithiated $F m \overline{3} m \mathrm{Ni}_{0.25} \mathrm{Mn}_{0.75} \mathrm{O}_{2}$ (see eq. $1 \mathrm{~b}$ showing the final delithiation of $\mathrm{LiNi}_{0.5} \mathrm{Mn}_{1.5} \mathrm{O}_{4}$ on charging).

$$
\begin{aligned}
\mathrm{Li}_{1 / 2}{ }^{8 a}\left(\mathrm{Ni}_{1 / 2} \mathrm{Mn}_{3 / 2}\right)^{16 d} \mathrm{O}_{4}^{32 e} \stackrel{\sim 3.22 \mathrm{~V} \text { vs.LTO }}{\stackrel{\sim}{\longrightarrow}} \\
2\left(\mathrm{Ni}_{1 / 4} \mathrm{Mn}_{3 / 4}\right)^{4 a} \mathrm{O}_{4}{ }^{4 b}+0.5 e^{-}+0.5 \mathrm{Li}^{+}
\end{aligned}
$$

Given that the measured charge-discharge curves are characteristic of the cathode but influenced by the anode, the incremental capacity plot is derived and shows only the anodic and cathodic peaks of the cathode. This is because of the $10 \%$ loading excess of the anode and the anode's flat charge/discharge plateau characteristics. The incremental capacity (Figure 3(d)) of the $5 \mathrm{~mA}$ cycle shows that the $\mathrm{Ni}^{2+} / \mathrm{Ni}^{3+}$ and $\mathrm{Ni}^{3+} / \mathrm{Ni}^{4+}$ peaks corresponding to the voltage plateaus in the charge-discharge curves are at 3.15/3.11 and 3.22/3.17 V, respectively. These potential peaks correlate to the phase evolution and reaction mechanism of the cathode material, as demonstrated by shifts in cathode reflection positions (Q value) (Figure 3 and eq. 1a) and the formation of new phases 
(Figure 3 and eq. 1b). Additionally, an inconspicuous anodic peak corresponding to the $\mathrm{Mn}^{3+} / \mathrm{Mn}^{4+}$ transition is observed at $2.92 \mathrm{~V}\left(\mathrm{vs} \mathrm{Li}_{4} \mathrm{Ti}_{5} \mathrm{O}_{12}\right)$. This is presumably related to a small $\mathrm{Mn}^{3+} / \mathrm{Mn}^{4+}$ transition that exhibits higher polarization than those of the $\mathrm{Ni}^{2+} / \mathrm{Ni}^{3+}$ and $\mathrm{Ni}^{3+} / \mathrm{Ni}^{4+}$ redox reactions in the cell. The absence of $\mathrm{Mn}^{3+} / \mathrm{Mn}^{4+}$ cathodic peak may be due to the voltage of this process lying lower than $2.4 \mathrm{~V}$ in this cell. We note that the battery design is specifically targeted for neutron diffraction measurements and modifications such as the use of deuterated electrolyte are known to affect battery performance.

Single-peak fitting shows that the $\mathrm{LiNi}_{0.5} \mathrm{Mn}_{1.5} \mathrm{O}_{4} 222$ and 004 reflections shift to higher $\mathrm{Q}$ value during charge to $3.15 \mathrm{~V}$ (during the $\mathrm{Ni}^{2+} / \mathrm{Ni}^{3+}$ oxidation plateau) and to a lower $\mathrm{Q}$ value during discharge (the $\mathrm{Ni}^{3+} / \mathrm{Ni}^{2+}$ reduction plateau). At voltages higher than $3.15 \mathrm{~V}$ (during the $\mathrm{Ni}^{3+} / \mathrm{Ni}^{4+}$ plateau) these reflections do not shift significantly, a fact that is likely associated with the degree of lithiation $\left(x\right.$ in $\left.\mathrm{Li}_{x} \mathrm{Ni}_{0.5} \mathrm{Mn}_{1.5} \mathrm{O}_{4}\right)$, reaching a minimum $\left(x^{\prime}\right)$. Further delithiation $(0.5 \sim x \geq 0)$, results in the formation of $\mathrm{Ni}_{0.25} \mathrm{Mn}_{0.75} \mathrm{O}_{2}$ via a two-phase reaction (Figure $3 \mathrm{~b}$ ). The value of $x$ ' is estimated to be approximately 0.5 at the beginning of the two-phase reaction, based on capacity and electrochemical considerations that indicate $\mathrm{Ni}$ ions are trivalent at this stage, in good agreement with the Rietveld refined value of $0.48(18)$. Overall, our analysis indicates 
that the $\mathrm{Ni}^{2+} / \mathrm{Ni}^{3+}$ redox couple results in a solid-solution reaction for the cathode (eq. 1a) such that $x$ in $\mathrm{Li}_{x} \mathrm{Ni}_{0.5} \mathrm{Mn}_{1.5} \mathrm{O}_{4}$ gradually decreases with charging voltage, whereas the $\mathrm{Ni}^{3+} / \mathrm{Ni}^{4+}$ redox couple initiates and corresponds to a two-phase reaction (eq. $1 \mathrm{~b}$ ). In contrast, Kunduraci et al. report successive two-phase reactions and three phases, correlated with different $\mathrm{Ni}$ oxidation states for both $F d \overline{3} m$ and $P 4_{3} 32$ spinel structures during electrochemical cycling, by investigating the $\mathrm{Li}_{x} \mathrm{Ni}_{0.5} \mathrm{Mn}_{1.5} \mathrm{O}_{4} 311$ reflection using XRD data [50]. The continuous change of the $\mathrm{LiNi}_{0.5} \mathrm{Mn}_{1.5} \mathrm{O}_{4}$ lattice, followed by phase segregation indicated by the $\mathrm{LiNi}_{0.5} \mathrm{Mn}_{1.5} \mathrm{O}_{4} 222$ and 004 reflection 'splitting' in our NPD data, strongly support the delithiation of $\mathrm{LiNi}_{0.5} \mathrm{Mn}_{1.5} \mathrm{O}_{4}$ through two successive reactions to form fully delithiated $\mathrm{Ni}_{0.25} \mathrm{Mn}_{0.75} \mathrm{O}_{2}$ in which the $\mathrm{Ni}^{2+} / \mathrm{Ni}^{3+}$ transition proceeds as a solid-solution reaction with a two-phase reaction taking place during the $\mathrm{Ni}^{3+} / \mathrm{Ni}^{4+}$ transition (Figure 4(a)). We note that the region identified as "no data" refers to a loss of data that occurred during the in-situ data collection.

In the $5 \mathrm{~mA}$ cycle, the lattice parameter of $\mathrm{LiNi}_{0.5} \mathrm{Mn}_{1.5} \mathrm{O}_{4}$ decreases from 8.1549(7) to $8.0798(8) \AA$ (dropping by $0.92(13) \%$ ) during charge to $3.19 \mathrm{~V}$, remains relatively unchanged during the 3.19 to $3.6 \mathrm{~V}$ charge and $3.6 \mathrm{~V}$ to $3.11 \mathrm{~V}$ discharge, and then increases from $8.0835(9)$ to $8.1487(8) \AA$ during discharge from 3.19 to $2 \mathrm{~V}$ (where the cell was held for 30 minutes). The lattice at 3.19 and $3.11 \mathrm{~V}$ that we determine from 
Rietveld analysis is in good agreement with the reported estimated lattice parameters of $\mathrm{Li}_{0.5} \mathrm{Ni}_{0.5} \mathrm{Mn}_{1.5} \mathrm{O}_{4}(a=8.09 \AA)$ [22], providing further evidence for the $x \sim 0.5$ composition at the end of the solid-solution reaction of the $\mathrm{Ni}^{2+} / \mathrm{Ni}^{3+}$ voltage plateau. Cycling with higher current, 9 and $18 \mathrm{~mA}$, yields a discharged $\mathrm{LiNi}_{0.5} \mathrm{Mn}_{1.5} \mathrm{O}_{4}$ lattice parameter of $8.1461(8)$ and $8.1445(8) \AA$, respectively. In the last cycle, where rapid charging and discharging at $90 \mathrm{~mA}$ were employed including constant-voltage holds at 3.6 and $2 \mathrm{~V}$ for 5 hours each, the lattice parameter of $\mathrm{LiNi}_{0.5} \mathrm{Mn}_{1.5} \mathrm{O}_{4}$ at the discharged state achieves a higher value (of 8.1460(7) $\AA$ ) than that during the $18 \mathrm{~mA}$ cycle, likely as a result of the longer voltage hold and the decreasing current, enabling more lithium intercalation relative to the $18 \mathrm{~mA}$ cycle. The readily-observable $\mathrm{LiNi}_{0.5} \mathrm{Mn}_{1.5} \mathrm{O}_{4}$ lattice change from charge to discharge (delithiation to lithiation) indicates a significant volume change during cycling with the variation of the lattice parameter indicating (approximately) the amount of lithium inserted or removed from the structure. The $\mathrm{LiNi}_{0.5} \mathrm{Mn}_{1.5} \mathrm{O}_{4}$ lattice parameter and change (\%) between different states of charge are summarized in Table 2. To assist in the understanding of the variation of lattice parameters at different applied currents, the charge/discharge capacities are also calculated and reported in Table 2. Compared with commercial $\mathrm{LiCoO}_{2}$ that exhibits a hexagonal-monoclinic phase change associated with a $2.6 \% c$-axis expansion between 
the charged and discharged states, the relatively small change in the $\mathrm{LiNi}_{0.5} \mathrm{Mn}_{1.5} \mathrm{O}_{4}$ lattice parameter upon electrochemical cycling is correlated with a better cycling performance [51, 52].

At the anode, it is known that the $\mathrm{Li}_{4} \mathrm{Ti}_{5} \mathrm{O}_{12} / \mathrm{Li}_{7} \mathrm{Ti}_{5} \mathrm{O}_{12}$ transition involves a two-phase reaction [53]. The information that can be extracted using Rietveld refinement is limited by the relatively small difference between the lattice parameters of $\mathrm{Li}_{4} \mathrm{Ti}_{5} \mathrm{O}_{12}$ and $\mathrm{Li}_{7} \mathrm{Ti}_{5} \mathrm{O}_{12}$, in addition to the resolution of the data in light of the $\mathrm{Li}_{4} \mathrm{Ti}_{5} \mathrm{O}_{12} / \mathrm{Li}_{7} \mathrm{Ti}_{5} \mathrm{O}_{12}$ reflections overlapping with those for the $\mathrm{Cu}$. In this study, the lattice evolution of anode is investigated by a single phase $\mathrm{Li}_{4+y} \mathrm{Ti}_{5} \mathrm{O}_{12}$ model. Upon cell cycling, a shift in the $\mathrm{Li}_{4+y} \mathrm{Ti}_{5} \mathrm{O}_{12} 222$ reflection $2 \theta$ position or $\mathrm{Q}$ value, indicating lattice change, is observed, but this shift is relatively small compared to those of the cathode reflections (Figure 4(b)). During cell charge, the $\mathrm{Q}$ value of $\mathrm{Li}_{4} \mathrm{Ti}_{5} \mathrm{O}_{12} 222$ reflection remains nearly unchanged at $2.5993 \AA^{-1}$ for first 300 minutes and increases slightly to $2.6014 \AA^{-1}$. The relatively small shift in this reflection illustrates that the anode's lattice parameter remains approximately unchanged $(0.05(1) \%$ lattice change) within the resolution of the measurement (changing from 8.3519(7) to 8.3474(7) $\AA$ ). As the cell is cycled at higher currents, 9 and $18 \mathrm{~mA}$, a relatively smaller reduction in the anode's lattice parameter, 0.04(1) and 0.03(2)\%, respectively, is obtained during charging. 
Besides the lattice parameters, the lithium occupation and oxygen positional parameter of both $\mathrm{LiNi}_{0.5} \mathrm{Mn}_{1.5} \mathrm{O}_{4}$ and $\mathrm{Li}_{4} \mathrm{Ti}_{5} \mathrm{O}_{12}$ can provide further insight into the structural changes that occur during cell cycling. The lithium occupation reflects lithiation and delithiation, and tracking the change in lithium occupation during cell cycling can provide an understanding of the lithiation/delithiation mechanism in both electrodes. Within $\mathrm{LiNi}_{0.5} \mathrm{Mn}_{1.5} \mathrm{O}_{4}$, lithium resides at the $8 a$ site, whereas lithium resides at two sites $(8 a$ and $16 c)$ in $\mathrm{Li}_{4} \mathrm{Ti}_{5} \mathrm{O}_{12}$ [47]. The transfer of lithium to and from the two sites in $\mathrm{Li}_{4} \mathrm{Ti}_{5} \mathrm{O}_{12}$ complicates the structural model used in the Rietveld analysis, and the lithiation/delithiation scenarios are instead derived from the integrated intensity of the $\mathrm{Li}_{4} \mathrm{Ti}_{5} \mathrm{O}_{12} / \mathrm{Li}_{4+y} \mathrm{Ti}_{5} \mathrm{O}_{12} 222$ reflection, which correlates to the formation of $\mathrm{Li}_{7} \mathrm{Ti}_{5} \mathrm{O}_{12}$ during lithiation. Furthermore, the oxygen positional parameter is indicative of the oxidation state of the transition metals during electrochemical cycling. Coulombic attraction will result in a shorter bond between a $M^{4+}$ transition metal and an oxygen atom than that between an oxygen atom and a $M^{3+}$ transition metal. As indicated in Table 1 , the smaller the value of the oxygen positional parameter $x(=y=z)$ the shorter the bond will be between the transition metal $\left(M=\mathrm{Mn} / \mathrm{Ni}\right.$ in $\mathrm{Li}_{x} \mathrm{Ni}_{0.5} \mathrm{Mn}_{1.5} \mathrm{O}_{4}$ and $\mathrm{Ti}$ in $\left.\mathrm{Li}_{4} \mathrm{Ti}_{5} \mathrm{O}_{12}\right)$ and the $\mathrm{O}$. The variation in the oxygen position indicates that the $M$-O bond shortens in the $\mathrm{Li}_{x} \mathrm{Ni}_{0.5} \mathrm{Mn}_{1.5} \mathrm{O}_{4}$ cathode (Figure 4(c)) and lengthens in the $\mathrm{Li}_{4+y} \mathrm{Ti}_{5} \mathrm{O}_{12}$ 
anode (Figure 4(d)) during charging, although the $\mathrm{Li}_{4+y} \mathrm{Ti}_{5} \mathrm{O}_{12}$ lattice shrinks (Figure 4(b)), and vice-versa during discharging. Ultimately, correlating the changes occurring to the lithium occupation and the oxygen positional parameter with the cell response is essential in understanding cell functionality, and consequently, gives insight into how important properties of the cell arise, such as capacity. The evolution of the oxygen positional parameter and lithium occupation in $\mathrm{Li}_{x} \mathrm{Ni}_{0.5} \mathrm{Mn}_{1.5} \mathrm{O}_{4}$, and the evolution of the oxygen positional parameter and $\mathrm{Li}_{4+y} \mathrm{Ti}_{5} \mathrm{O}_{12} 222$ reflection intensity, are plotted in Figures 4(c) and 4(d), respectively. We note that the lithium occupation in $\mathrm{Li}_{x} \mathrm{Ni}_{0.5} \mathrm{Mn}_{1.5} \mathrm{O}_{4}$ remains nearly constant at $50 \%$ across the two-phase region.

Colin et al. [54] report that the $\mathrm{Li}_{7} \mathrm{Ti}_{5} \mathrm{O}_{12}$ 773/666 reflection intensities change alongside lithium position and/or occupation as a consequence of the diffusion of lithium from the $8 a$ to the $16 c$ site in $\mathrm{Li}_{7} \mathrm{Ti}_{5} \mathrm{O}_{12}$. In order to understand the effect of lithium location and occupation within the $\mathrm{Li}_{4+y} \mathrm{Ti}_{5} \mathrm{O}_{12}$ anode on the NPD data, NPD patterns are calculated. The calculated NPD patterns clearly show an increasing intensity of the 222 reflection upon transition from $\mathrm{Li}_{4} \mathrm{Ti}_{5} \mathrm{O}_{12}$ to $\mathrm{Li}_{4+y} \mathrm{Ti}_{5} \mathrm{O}_{12}$ that occurs upon initial lithiation, and then to $\mathrm{Li}_{7} \mathrm{Ti}_{5} \mathrm{O}_{12}$ occurring upon further lithiation (Figure 5). Such changes in intensity occur when lithium ions at tetrahedral $(8 a)$ sites are transferred to octahedral (16c) sites, where the $16 c$ site can accommodate twice as much lithium as the 
$8 a$ site. Furthermore, the $\mathrm{O}$ atom moves further away from the transition metal as the average valence of the Ti decreases from $4+$ to $3.4+$ during charge (Figure 4(d)). This structural change is associated with changes in the intensity of the measured $\mathrm{Li}_{4+y} \mathrm{Ti}_{5} \mathrm{O}_{12}$ 222 reflection that are consistent with those previously reported [54], where the intensity is relatively higher at lithiated states and lower at delithiated states. The oxygen positional parameter and $\mathrm{Li}_{4} \mathrm{Ti}_{5} \mathrm{O}_{12} / \mathrm{Li}_{4+y} \mathrm{Ti}_{5} \mathrm{O}_{12} 222$ reflection intensity changes during charge/discharge provide a more complete picture of the structural changes of $\mathrm{Li}_{4} \mathrm{Ti}_{5} \mathrm{O}_{12}$ when used as an anode in the $\mathrm{LiNi}_{0.5} \mathrm{Mn}_{1.5} \mathrm{O}_{4} \| \mathrm{Li}_{4} \mathrm{Ti}_{5} \mathrm{O}_{12}$ cell.

For $\mathrm{Li}_{\mathrm{x}} \mathrm{Ni}_{0.5} \mathrm{Mn}_{1.5} \mathrm{O}_{4}$ on charge (delithiation of the cathode), lithium occupation (at the $8 a$ site) decreases gradually from $99(13)$ to $57(19) \%$ when the Ni valence increases from $2+$ to $3+$ (during the solid-solution transition). On further charge, the lithium occupation in $\mathrm{Li}_{x} \mathrm{Ni}_{0.5} \mathrm{Mn}_{1.5} \mathrm{O}_{4}$ is presumably unchanged as the lattice parameters, although the amount of $\mathrm{Li}_{x} \mathrm{Ni}_{0.5} \mathrm{Mn}_{1.5} \mathrm{O}_{4}$ in the cathode decreases as $\mathrm{Ni}_{0.25} \mathrm{Mn}_{0.75} \mathrm{O}_{2}$ is formed during the $\mathrm{Ni}^{3+} / \mathrm{Ni}^{4+}$ transition (a two-phase reaction). To accurately characterize the $\mathrm{Ni}_{0.25} \mathrm{Mn}_{0.75} \mathrm{O}_{2}$ crystal structure, an individual refinement using the NPD pattern collected at 3.6 V was performed (at the charged state of the cell after a 30-minute hold), where the cathode contains the largest fraction of the $\mathrm{Ni}_{0.25} \mathrm{Mn}_{0.75} \mathrm{O}_{2}$ phase in the two-phase region. The Rietveld fit is shown in Figure S3 and the crystallographic 
parameters are presented in Table S3 in the Supporting Information. On discharge, the lithium occupation in $\mathrm{Li}_{x} \mathrm{Ni}_{0.5} \mathrm{Mn}_{1.5} \mathrm{O}_{4}$ increases from $\sim 50$ to $100 \%$ when trivalent $\mathrm{Ni}$ is reduced to $2+$ (via a solid-solution reaction) after the completion of the two-phase reaction (marked by the disappearance of the $\mathrm{Ni}_{0.25} \mathrm{Mn}_{0.75} \mathrm{O}_{2}$ phase). This result supports the proposed solid-solution and two-phase reaction of the $\mathrm{Li}_{x} \mathrm{Ni}_{0.5} \mathrm{Mn}_{1.5} \mathrm{O}_{4}$ cathode. It is found that in $\mathrm{Li}_{x} \mathrm{Ni}_{0.5} \mathrm{Mn}_{1.5} \mathrm{O}_{4}$ the $\mathrm{O}$ approaches the $\mathrm{Ni}$ when its valence increases from $2+$ to $3+$, and vice-versa, following the expected trend of the oxidation/reduction of the transition metal species at the centre of the $\mathrm{O}$ octahedron in these compounds. An abnormal trend is observed in the $\mathrm{Li}_{x} \mathrm{Ni}_{0.5} \mathrm{Mn}_{1.5} \mathrm{O}_{4}$ cathode when it is either delithiated or lithiated close to $\sim 50 \%$ lithiated, which may correlate with lithium population at the $16 c$ crystallographic site, as proposed in $\mathrm{LiMn}_{2} \mathrm{O}_{4}[36,55]$, or may suggest a structural transition arising from the possible migration of transition metal cations (e.g. $8 a$ to $16 c$ ) during $\mathrm{Li}$ insertion [21]. We note that in the two-phase region the cathode phases undergo an increase/decrease in weight fraction (intensity/amplitude) and that structural variables such as lattice parameter, oxygen positional parameter, and lithium occupation, remain constant, and therefore these are not included in the figures. The relative phase abundance of $\mathrm{Li}_{0.5} \mathrm{Ni}_{0.5} \mathrm{Mn}_{1.5} \mathrm{O}_{4}, \mathrm{Ni}_{0.25} \mathrm{Mn}_{0.75} \mathrm{O}_{2}$, and $\mathrm{Li}_{4} \mathrm{Ti}_{5} \mathrm{O}_{12}$ (as well as the electrochemically inactive and unchanging $\mathrm{Al}$ and $\mathrm{Cu}$ ) during the two-phase reaction 
region as estimated from Rietveld analysis are shown in Figure 4(e). At the beginning of two-phase region, the amount of $\mathrm{Ni}_{0.25} \mathrm{Mn}_{0.75} \mathrm{O}_{2}$ is below the detection limit of NPD. As the $\mathrm{Ni}_{0.25} \mathrm{Mn}_{0.75} \mathrm{O}_{2}$ amount increases above the detection limit, Rietveld analysis indicates an increase in the $\mathrm{Ni}_{0.25} \mathrm{Mn}_{0.75} \mathrm{O}_{2}$ relative abundance that is associated with a similarly dramatic decrease in the relative abundance of the $\mathrm{Li}_{0.5} \mathrm{Ni}_{0.5} \mathrm{Mn}_{1.5} \mathrm{O}_{4}$ phase, a phenomenon indicative of the two-phase transition of the $\mathrm{Ni}^{3+} / \mathrm{Ni}^{4+}$ redox plateau. We also find that the relative phase abundance of $\mathrm{Li}_{4+y} \mathrm{Ti}_{5} \mathrm{O}_{12}$ increases and decreases slightly as a result of formation of lithiated $\mathrm{Li}_{7} \mathrm{Ti}_{5} \mathrm{O}_{12}$ and delithiated $\mathrm{Li}_{4} \mathrm{Ti}_{5} \mathrm{O}_{12}$, respectively. Furthermore, it is also found that the decrease in the relative phase abundance of $\mathrm{Li}_{0.5} \mathrm{Ni}_{0.5} \mathrm{Mn}_{1.5} \mathrm{O}_{4}$ is not equal to the commensurate increase in the relative phase abundance of $\mathrm{Ni}_{0.25} \mathrm{Mn}_{0.75} \mathrm{O}_{2}$. This result may arise from changing crystallinity of the cathode, such as if the $\mathrm{Ni}_{0.25} \mathrm{Mn}_{0.75} \mathrm{O}_{2}$ phase had a lower crystallinity than the $\mathrm{Li}_{0.5} \mathrm{Ni}_{0.5} \mathrm{Mn}_{1.5} \mathrm{O}_{4}$ phase, influencing the relative phase abundance determined using the Rietveld method. Such an effect may explain the relatively small differences that we observe between the evolution of the phase fractions of $\mathrm{Ni}_{0.25} \mathrm{Mn}_{0.75} \mathrm{O}_{2}$ and $\mathrm{Li}_{0.5} \mathrm{Ni}_{0.5} \mathrm{Mn}_{1.5} \mathrm{O}_{4}$, obtained using Rietveld analysis, and our measured charge-discharge curves. It can be also the lithium go into other phases that are amorphous or not considered previously. We note also the formation of a relatively smaller quantity of 
$\mathrm{Ni}_{0.25} \mathrm{Mn}_{0.75} \mathrm{O}_{2}$ at higher, compared to lower, current, which is consistent with the extraction of less lithium from the cathode.

We make a brief comment on the lattice parameter evolution of the cathode and anode during the last cycle performed, where rapid charging/discharging and constant-voltage steps at 3.6 and $2.0 \mathrm{~V}\left(\mathrm{vs} \mathrm{Li}_{4} \mathrm{Ti}_{5} \mathrm{O}_{12}\right)$ are applied, see Figure $4(\mathrm{~d})$. We note that statistically better NPD data are collected during the constant-voltage charge and discharge steps that during the rapid voltage increases to $3.6 \mathrm{~V}$ and decreases to 2.0 $\mathrm{V}$ during charge/discharging of the cell at $90 \mathrm{~mA}$. During the galvanostatic charge and discharge, rapid changes in the lattice parameters of both the cathode and anode are observed as a result of the higher applied current, whereas during the constant-voltage charge the lattice parameters of both the $\mathrm{LiNi}_{0.5} \mathrm{Mn}_{1.5} \mathrm{O}_{4}$ and $\mathrm{Li}_{4} \mathrm{Ti}_{5} \mathrm{O}_{12}$ electrodes decrease gradually, but differently. During the constant-voltage discharge, the lattice parameters of both $\mathrm{LiNi}_{0.5} \mathrm{Mn}_{1.5} \mathrm{O}_{4}$ and $\mathrm{Li}_{4} \mathrm{Ti}_{5} \mathrm{O}_{12}$ increase more slowly than their commensurate increase during the constant-voltage charge, and remain relatively unchanged at $8.147(1)$ and $8.3515(4) \AA$, respectively. The different lattice parameter profiles during the constant-voltage charge and discharge can be explained through an examination of the accumulated capacity during the constant-voltage steps. As shown in Figure S4 (Supporting Information), the galvanostatic charge contributes approximately 
$9 \%$ of the charging capacity, whereas the galvanostatic discharge provides approximately $98 \%$ of the discharging capacity of the cycle. The capacity during the constant-voltage discharge only contributes $\sim 2 \%$ of the discharge capacity, suggesting that no further lithiation occurs and, consequently, the lattice parameters remain nearly unchanged. The capacity profile is in excellent agreement with the changes in the calculated lattice parameters of both $\mathrm{LiNi}_{0.5} \mathrm{Mn}_{1.5} \mathrm{O}_{4}$ and $\mathrm{Li}_{4} \mathrm{Ti}_{5} \mathrm{O}_{12}$. It is also noteworthy that the charge/discharge capacities delivered from the $90 \mathrm{~mA}$ cycle with constant-voltage steps are close to those obtained during the $9 \mathrm{~mA}$ cycle without constant-voltage steps, demonstrating that the $\mathrm{LiNi}_{0.5} \mathrm{Mn}_{1.5} \mathrm{O}_{4} \| \mathrm{Li}_{4} \mathrm{Ti}_{5} \mathrm{O}_{12}$ cell shows potential for high-power applications. To further explore this possibility, a detailed study of the structural evolution of these electrodes during fast charge/discharge is planned in future experiments. The origin of the significant irreversible capacity loss during the 5 $\mathrm{mA}$ cycle is also under investigation.

\section{Conclusions}

A novel neutron-friendly $\mathrm{LiNi}_{0.5} \mathrm{Mn}_{1.5} \mathrm{O}_{4} \| \mathrm{Li}_{4} \mathrm{Ti}_{5} \mathrm{O}_{12}$ cell containing deuterated electrolyte and PVDF separator was used for the first-time in an in-situ NPD experiment. This study reveals important information concerning the crystallographic 
evolution of the $\mathrm{LiNi}_{0.5} \mathrm{Mn}_{1.5} \mathrm{O}_{4}$ and $\mathrm{Li}_{4} \mathrm{Ti}_{5} \mathrm{O}_{12}$ electrodes in the cell during charge-discharge cycling. In the $\mathrm{LiNi}_{0.5} \mathrm{Mn}_{1.5} \mathrm{O}_{4}$ cathode, solid-solution and two-phase transitions are confirmed for the $\mathrm{Ni}^{2+} / \mathrm{Ni}^{3+}$ and $\mathrm{Ni}^{3+} / \mathrm{Ni}^{4+}$ redox couples, respectively. The measured oxygen positional parameter was used as an indicator for the valence of the transition metals that support the redox reactions taking place. The position of the oxygen atom (32e site) and the lithium occupation ( $8 a$ site) in $\mathrm{LiNi}_{0.5} \mathrm{Mn}_{1.5} \mathrm{O}_{4}$ during charge-discharge cycling are shown and correlated with the delithiation/lithiation processes. The phase composition of the cathode during charge/discharge is determined, revealing a two-phase reaction producing the $\mathrm{Ni}_{0.25} \mathrm{Mn}_{0.75} \mathrm{O}_{2}$ secondary phase with the refined lattice parameter of $4.000(7) \AA$. For the anode, the changes in both the $\mathrm{Li}_{4+y} \mathrm{Ti}_{5} \mathrm{O}_{12} 222$ reflection intensity and oxygen positional parameter are consistent with the description of the lithium intercalation/deintercalation processes of $\mathrm{Li}_{4} \mathrm{Ti}_{5} \mathrm{O}_{12}$ upon cycling. The crystallographic volume change of the $\mathrm{LiNi}_{0.5} \mathrm{Mn}_{1.5} \mathrm{O}_{4}$ and $\mathrm{Li}_{4} \mathrm{Ti}_{5} \mathrm{O}_{12}$ electrodes are determined at different applied currents, and reveal a smaller volume change that is correlated to a loss in capacity at higher, compared with lower, current.

\section{Acknowledgments}


The authors acknowledge the research funding provided by the National Science Council of Taiwan through the project (NSC99-2632-E-036-001-MY3), and the travel support funded by National Synchrotron Radiation Research Center (proposal 2012-2-123-1). The authors are also grateful to Professor Lin, Jeng-Yu of Tatung University for providing $\mathrm{Li}_{4} \mathrm{Ti}_{5} \mathrm{O}_{12}$ samples and the staff members at the Bragg Institute, ANSTO for their operations support.

\section{Associated Content}

XRPD patterns of the as-prepared electrode materials (Figure S1), results from single-peak fitting of the NMO 222 reflection (Figure S2), Rietveld-refinement plot using the in-situ NPD pattern of the battery during the state of charge yielding the most $\mathrm{Ni}_{0.25} \mathrm{Mn}_{0.75} \mathrm{O}_{2}$ phase within the two-phase region (Figure $\mathrm{S} 3$ ), capacity profile during constant-voltage steps (Figure S4), along with figures of merit for Rietveld refinements using the in-situ NPD data (Table $\mathrm{S} 1$ ), $\mathrm{R}_{\mathrm{B}}$ and $\mathrm{R}_{\mathrm{F}}$ ranges for Rietveld refinements using the in-situ NPD data (Table S2), and the figure-of-merits and calculated lattice parameters using the NPD pattern of the cell during the state of charge yielding the most $\mathrm{Ni}_{0.25} \mathrm{Mn}_{0.75} \mathrm{O}_{2}$ phase within the two-phase region (Table S3), are given as Supporting Information. 


\section{References:}

[1] S.S. Zhang, J. Power Sources, 161 (2006) 1385-1391.

[2] T. Ohzuku, A. Ueda, N. Yamamoto, J. Electrochem. Soc., 142 (1995) 1431-1435.

[3] Y.-B. He, Z.-Y. Tang, Q.-S. Song, H. Xie, Y.-G. Liu, Q. Xu, J. Electrochem. Soc., 155 (2008) A481-A487.

[4] L. Shen, X. Zhang, E. Uchaker, C. Yuan, G. Cao, Adv. Energy Mater., 2 (2012) 691-698.

[5] J. Shu, Electrochem. Solid-State Lett., 11 (2008) A238-A240.

[6] C. Wang, A.J. Appleby, F.E. Little, Electrochim. Acta, 46 (2001) 1793-1813.

[7] P.G. Bruce, B. Scrosati, J.-M. Tarascon, Angew. Chem. Int. Ed. , 47 (2008) 2930-2946.

[8] I. Belharouak, Y.-K. Sun, W. Lu, K. Amine, J. Electrochem. Soc., 154 (2007) A1083-A1087.

[9] K. Amine, J. Liu, I. Belharouak, Electrochem. Comm., 7 (2005) 669-673.

[10] K. Mizushima, P.C. Jones, P.J. Wiseman, J.B. Goodenough, Mater. Res. Bull., 15 (1980) 783-789. 
[11] A.K. Padhi, K.S. Nanjundaswamy, J.B. Goodenough, J. Electrochem. Soc., 144 (1997) 1188-1194.

[12] C.Y. Yang, C.H. Cheng, S.M. Ho, J.C. Chen, W.M. Hurng, J. Power Sources, 68 (1997) 440-442.

[13] H.M. Wu, I. Belharouak, H. Deng, A. Abouimrane, Y.-K. Sun, K. Amine, J. Electrochem. Soc., 156 (2009) A1047-A1050.

[14] H.F. Xiang, X. Zhang, Q.Y. Jin, C.P. Zhang, C.H. Chen, X.W. Ge, J. Power Sources, 183 (2008) 355-360.

[15] J.C. Arrebola, A. Caballero, L. Hernan, J. Morales, J. Nanomater., 2008 (2008) 10 pages. doi:10.1155/2008/659397.

[16] K. Ariyoshi, S. Yamamoto, T. Ohzuku, J. Power Sources, 119-121 (2003) 959-963.

[17] L. My-Loan-Phung, P. Strobel, C.V. Colin, T. Pagnier, F. Alloin, J. Phys. Chem. Solids, 72 (2011) 124-135.

[18] D. Pasero, N. Reeves, V. Pralong, A.R. West, J. Electrochem. Soc., 155 (2008) A282-A291.

[19] X.Y. Feng, C. Shen, X. Fang, C.H. Chen, J Alloys Compd., 509 (2011) 3623-3626. 
[20] J.-H. Kim, C.S. Yoon, S.-T. Myung, J. Prakash, Y.-K. Sun, Electrochem. Solid-State Lett., 7 (2004) A216-A220.

[21] J.H. Kim, S.T. Myung, C.S. Yoon, S.G. Kang, Y.K. Sun, Chem. Mater., 16 (2004) 906-914.

[22] K. Ariyoshi, Y. Iwakoshi, N. Nakayama, T. Ohzuku, J. Electrochem. Soc., 151 (2004) A296-A303.

[23] J. Cho, Y.J. Kim, T.-J. Kim, B. Park, Angewandte Chemie, 113 (2001) 3471-3473.

[24] F. Ronci, P. Reale, B. Scrosati, S. Panero, V. Rossi Albertini, P. Perfetti, M. di Michiel, J.M. Merino, J. Phys. Chem. B, 106 (2002) 3082-3086.

[25] S. Panero, P. Reale, F. Ronci, B. Scrosati, P. Perfetti, V. Rossi Albertini, Phys. Chem. Chem. Phys., 3 (2001) 845-847.

[26] A. Bhaskar, N.N. Bramnik, A. Senyshyn, H. Fuess, H. Ehrenberg, J. Electrochem. Soc., 157 (2010) A689-A695.

[27] L. Cai, Z. Liu, K. An, C. Liang, J. Mater. Chem. A, 1 (2013) 6908-6914.

[28] H. Berg, H. Rundlöv, J.O. Thomas, Solid State Ionics, 144 (2001) 65-69.

[29] L. Cai, K. An, Z. Feng, C. Liang, S.J. Harris, J. Power Sources, 236 (2013) 163-168. 
[30] G. Du, N. Sharma, V.K. Peterson, J.A. Kimpton, D. Jia, Z. Guo, Adv. Func. Mater., 21 (2011) 3990-3997.

[31] N. Sharma, G. Du, A.J. Studer, Z. Guo, V.K. Peterson, Solid State Ionics, 199-200 (2011) 37-43.

[32] N. Sharma, X. Guo, G. Du, Z. Guo, J. Wang, Z. Wang, V.K. Peterson, J. Am. Chem. Soc., 134 (2012) 7867-7873.

[33] N. Sharma, V.K. Peterson, Electrochim. Acta, 101 (2013) 79-85.

[34] N. Sharma, V.K. Peterson, M.M. Elcombe, M. Avdeev, A.J. Studer, N. Blagojevic, R. Yusoff, N. Kamarulzaman, J. Power Sources, 195 (2010) 8258-8266.

[35] N. Sharma, M.V. Reddy, G. Du, S. Adams, B.V.R. Chowdari, Z. Guo, V.K. Peterson, J. Phys. Chem. C, 115 (2011) 21473-21480.

[36] N. Sharma, D. Yu, Y. Zhu, Y. Wu, V.K. Peterson, Chem. Mater., 25 (2013) 754-760.

[37] N. Sharma, V.K. Peterson, J. Power Sources, (2013) In Press.

[38] K.-D. Liss, B. Hunter, M. Hagen, T. Noakes, S. Kennedy, Physica B, 385-386, Part 2 (2006) 1010-1012. 
[39] B. Hunter, in, International Union of Crystallography Commission on Powder Diffraction Newsletter No. 20, (Summer) http://www.rietica.org, 1998.

[40] A.J. Studer, M.E. Hagen, T.J. Noakes, Physica B, 385-386, Part 2 (2006) 1013-1015.

[41] T. Roisnel, J. Rodriguez-Carvajal, in: R. Delhez, E.J. Mittenmeijer (Eds.) Materials Science Forum, Proceedings of the Seventh European Powder Diffraction Conference (EPDIC 7), 2000, pp. 118-123.

[42] J. Rodríguez-Carvajal, Physica B, 192 (1993) 55-69.

[43] D. Richard, M. Ferrand, G.J. Kearley, J. Neutron Res., 4 (1996) 33-39.

[44] E. Konysheva, E. Suard, J.T.S. Irvine, Chem. Mater., 21 (2009) 5307-5318.

[45] M. Kunduraci, G.G. Amatucci, J. Power Sources, 165 (2007) 359-367.

[46] T.A. Arunkumar, A. Manthiram, Electrochim. Acta, 50 (2005) 5568-5572.

[47] K. Kataoka, Y. Takahashi, N. Kijima, J. Akimoto, K.-i. Ohshima, J. Phys. Chem. Solids, 69 (2008) 1454-1456.

[48] K. Kataoka, Y. Takahashi, N. Kijima, H. Nagai, J. Akimoto, Y. Idemoto, K. Ohshima, Mater. Res. Bull., 44 (2009) 168-172. 
[49] J. Akimoto, Y. Takahashi, Y. Gotoh, K. Kawaguchi, K. Dokko, I. Uchida, Chem. Mater., 15 (2003) 2984-2990.

[50] M. Kunduraci, G.G. Amatucci, J. Electrochem. Soc., 153 (2006) A1345-A1352.

[51] J.N. Reimers, J.R. Dahn, J. Electrochem. Soc., 139 (1992) 2091-2097.

[52] S.A. Needham, G.X. Wang, H.K. Liu, V.A. Drozd, R.S. Liu, J. Power Sources, 174 (2007) 828-831.

[53] S. Scharner, W. Weppner, P. Schmid-Beurmann, J. Electrochem. Soc., 146 (1999) $857-861$.

[54] J.-F. Colin, V. Godbole, P. Novák, Electrochem. Comm., 12 (2010) 804-807.

[55] H. Berg, K. Goransson, B. Nolang, J.O. Thomas, J. Mater. Chem., 10 (2000) $1437-1441$ 